\title{
Towards a Model for the Development and Assessment of Competences through Formative Projects
}

\author{
Sergio Cardona \\ Universidad del Quindío, Facultad de Ingeniería \\ Armenia, Colombia \\ sergio_cardona@uniquindio.edu.co \\ Jeimy Vélez \\ Pontificia Universidad Bolivariana, Facultad de Ingeniería \\ Montería, Colombia \\ jeimy.velez@upb.edu.co \\ and \\ Sergio Tobón \\ Corporación Universitaria CIFE \\ Cuernavaca, México \\ contacto@cife.ws
}

\begin{abstract}
The competence-based formation model has oriented educational policies in different countries during the last decades. From this model, the socioformative approach has its basis and works as a referent in Latin America to orient the formation and competence assessment. The socioformative approach uses the methodology of the formative projects by means of an articulated set of pedagogical strategies that are used along the time to solve the problems of the context. This paper presents a model for competences development and assessment using formative projects as part of a technological architecture to personalize the students' educational experience through a Learning Management System. Finally, a case study is presented to validate the proposed model with formation methodology in a virtual course.
\end{abstract}

Keywords: assessment model; competence; formative projects; socioformative approach; project based learning.

\section{Introduction}

During the last decades, the education reforms have been structured on a large scale in several western countries [1]. A general motivation to guide the quality policies of education towards new educational principles focused on a vision for competence-based education is identified. Projects like Tuning from the European Union, Alfa Tuning Latin-America, the DeSeCo Project (Spanish for Definition and Selection of Competences), CORE (CORE Project Competences in Education and Cross border Recognition), demonstrate so.

Different approaches appear with the emergence of the competences in education including the socioformative proposed by Tobón in the late nineties. The socioformative approach incorporates the fundamental principles of project-based learning. It proposes a methodology for the formation and assessment of competencies through formation projects, which consist of articulated activities oriented to interpret, argue and solve context problems.

Considering that the theoretical foundations around competence formation have been widely investigated, technological solutions for virtual learning environments are being developed currently which seek to facilitate the educational process of students. However, in many cases these solutions are not supported by a pedagogical approach that guides a whole educational process, they do not identify the proficiency levels of students, and lack a system of formative evaluation that allows making a personalized tracking of the students learning process. 
Due to the complexity in competence formation, it is necessary to define a model that considers the design elements needed to guide a system of competence formation and assessment. The proposed model is consistent with the pedagogical principles of the socioformative approach, and it is based on the methodology of formation projects where the definition of competences, the criteria statement, and the delivery of evidence are considered. Also, an assessment structure is defined in the model where the proficiency levels of competence and the types of evaluation that are applied during all stages of the learning process of students are considered.

On the other hand, everyday more institutions use LMS to enrich the formation scenarios and encourage people learning. However, it is frequent to see from the LMS the offering of learning resources to students in a generalized way without considering issues that may be significant in an individual manner to develop their competences. Some of them do not consider students' own differences and therefore cannot be configured to customize the student learning environment [2]. These differences impact, as each student can have different motivations, interests and levels of knowledge. Based on the above, there is the importance of personalization in which the behavior of a system is adapted to specific characteristics of people, allowing defining alternatives adapted to individual peculiarities, seeking a process of learning, monitoring and evaluating competences more satisfactorily. This proposal presents a model for competences development and assessment as part of a technological architecture to personalize the students' educational experience through a virtual learning environment.

This paper is organized as follows: Chapter 2 presents the framework with the fundamental concepts of the competences, assessment of competences, and project-based learning. Chapter 3 shows an analysis of works related to academic experiences based on project-based learning, models, and assessment types. The theoretical foundation of the formation project is presented in Chapter 4. Chapter 5 describes the formation project model under the socioformative approach. A case study that illustrates the application of the methodology of the formation projects in a virtual course from CIFE University Corporation of Mexico is presented in Chapter 6. Finally, conclusions and future work proposals are shown.

\section{Framework}

The framework contains the theoretical elements that support the model. The concepts of competences, competence assessment, and Project based learning will be shown.

\subsection{Competences}

For the past decades, the competence concept has been employed in the human talent development area where the people's performance in specific work situations is evaluated. In the 1990's, the competences begin to be implemented by the influence of globalization, talent management, and the quality assurance systems[3]. The historical development of the concept of competences in different fields is evidenced in [3] and [4]. The concept of competences is found on [5] and [6], and it is defined as attribute structures (knowledge, attitudes, values, skills) needed to face situations from the context (tasks, activities, and problems), which integrate diverse dimensions of the human being, acting contexts, and multiple disciplines. The definitions integrate diverse dimensions of people, relate ethical aspects, and emphasize in the attitudes, skills and knowledge [7]. Table 1 presents definitions of the concept competences [8].

Table 1: Concepts of Competence

\begin{tabular}{|c|c|}
\hline Author & Description \\
\hline $\begin{array}{l}\text { Gonczi \& } \\
\text { Athanasou }[5]\end{array}$ & $\begin{array}{l}\text { Complex structure of attributes (knowledge, attitude, values and abilities) necessary for } \\
\text { the interpretation and performance in specific situations, having in mind the context; } \\
\text { incorporating ethics and values as fundamental elements. }\end{array}$ \\
\hline Ouellet, [9] & $\begin{array}{l}\text { Set of specific attitudes, abilities and knowledge that make a person able to do a job or to } \\
\text { solve a problem. }\end{array}$ \\
\hline Perrenoud, [10] & $\begin{array}{l}\text { Aptitude to confront efficiently analogue situations, mobilizing consciously, pertinently } \\
\text { and creatively multiple cognitive resources: knowledge, ability, values, attitude, } \\
\text { evaluation and reasoning schemes. }\end{array}$ \\
\hline DeSeCo, [11] & $\begin{array}{l}\text { Ability to confront complex demands, relying on/and mobilizing psychosocial resources } \\
\text { (skills and attitudes) in a particular context. }\end{array}$ \\
\hline Tuning, [12] & $\begin{array}{l}\text { Represent a mixture of attributes (regarding knowledge and its applications, aptitudes, } \\
\text { skills and responsibilities) that describe the level or sufficiency degree that a person can } \\
\text { perform. }\end{array}$ \\
\hline
\end{tabular}

Athanasou and Gonczi [5], [13], [14], recognize the existence of different perspectives on the competences approach; some of which are presented in [13] and [14]. Various classifications of competences are also proposed in 
[13], [14], [15] y [16]. All of these approaches and classifications show great variability according to their context of application, and as it is stated by [17], it is recognized the conceptual complexity of the competences taking into account that in the context of education a consensual acceptation around them does not exist. These approaches have common elements as well as methodological differences to form and assess the competences in people.

Within the educational model of competence, the socio-formative approach appears, it guides the formation and evaluation using the methodology of formative projects [3]. A formative project is a set of activities that are being deployed with time to solve a contextualized problem and to contribute to form one or several competences based on criteria and evidence [18]. The formative project constitutes the organizational element that guides, through phases, the implementation of activities that allows reaching performance levels by the development of evidence.

For Tobón [3] the competences are integral actions to resolve context problems with appropriateness, continuous improvement, and ethical commitment. They consist of underlying processes (cognitive-affective) as well as public and provable processes, while they always imply an action from themselves to others and/or the context. With this approach based on complex thinking, the addressing of competences around tasks and activities that currently are meaningless against the challenge of formation for the society of knowledge is transcended.

\subsection{Competence Assessment}

The competence approach in education has transformed the traditional assessment practices where the emphasis is shifting from the specific knowledge to comprehensive performances regarding environmental problems. It is recognized that many of the traditional assessment practices are applied and remain valid. They meet the needs of a summative judgment, but they do not monitor the learning process. Quellmalz and Pellegrino [19] made a distinction between the summative assessment, usually aimed at the assessment of learning outcomes for classification purposes. And the formative assessment used to diagnose and modify the learning conditions. As Zabalza suggests [20], the more formative the assessment is and the greater the educational potential has, the higher its informative level is.

This entails the definition of continuous monitoring activities ranging from the assessment proposal to the validation of the evidence with its respective valuation

From the socio-formation, it is proposed the concept of assessment, rather than evaluation, to highlight the appreciative, recognizing, and formative character that every assessment process in the social context should have [1]. This model emphasizes on the evaluation of people based on context problems: At the beginning (diagnosis assessment), during the formation development (continuous assessment), at the end of the formation (assessment for the accreditation), and after graduation in the context (socio-assessment).

In a formative process by competences, several types of assessment are employed. [21] and [22] describe the socalled new assessment processes which are: self-assessment, portfolio, 360 degree evaluation with feedback, peerassessment, hereto-assessment among others. Table 2 shows a description of some types of assessment

Table 2: Assessment Types

\begin{tabular}{|c|c|}
\hline Type & Description \\
\hline 360 degrees & All the people involved in the formation process evaluate the person's work. \\
\hline Self Assessment & $\begin{array}{l}\text { It occurs when a person, group of people, corporation, or state, assess their own } \\
\text { competences to some criteria and evidence. }\end{array}$ \\
\hline Peer Assessment & It is peer assessment (individuals or groups of the same level. \\
\hline Hetero Assessment & The evaluation is performed by an expert in the area. \\
\hline Portfolio & $\begin{array}{l}\text { Considers the collection of work evidence that allows students and teachers to } \\
\text { monitor the progress, difficulties, and success in formation. }\end{array}$ \\
\hline
\end{tabular}

Likewise, there are models to support processes and activities for e-assessment, [21] and [23]. Also, there are technological tools that support assessment types in formative scenarios [24] and [25], customized systems that allow feedback to students [26] and [27], tools for the formation and evaluation of knowledge in specific areas [28], and simulation tools to measure the levels of knowledge [19].

\subsection{Project Method}

The Project Method emerges as an innovative methodology for the formation of people worldwide. This method was conceptualized by Kilpatrick [29], who considered a project as an intentional act in the context of education. Its goal enables people to acquire knowledge through practice in a particular social context emphasizing the authenticity and autonomy in the learning process. This method comprises a whole learning process that starts from an initial idea of the project to its potential solutions where according to Kilpatrick [29] four phases must be executed : proposal , planning, implementation and evaluation. All these steps require the completion of activities in which the student plays an active role in his formation; incorporating among others, motivational aspects, self-regulation, mediation, cooperation and collaboration, aimed at solving a problem considering its variables and constraints. In Adderley et 
al. [30] some features of the method of projects are highlighted :

They involve the solution of a problem and often result in a final product.

They involve the initiative of a student or group of students with a variety of educational activities.

The teaching staff is involved as an advisor in any or all stages of the project.

The design of a project in the educational context should consider different aspects. Osada and Miyake [31] include: the timing of the project with the description of each one of the activities that the students must complete. The configuration of the project where the students must apply the knowledge in their field of discipline based on an understanding of the activities, and the project selection based on the interests of students.

Some critical factors for the formation project management have been highlighted and exposed by Pucher and Lehner in[32]:

Inexperience of the students in project management.

Motivational aspects of the students.

The interactions of teachers with students depend on factors associated to the specific experience of a teacher in a specific project.

The method of projects in education is a pedagogical method that gives students the opportunity to learn the problem in depth. It facilitates the obtaining of knowledge independently and the development of skills such as the communication competence, the spirit of teamwork, the use of computer technology, the initiative and confidence in their own work [33].

\subsection{Project-based learning}

Project-based learning (PBL) has been incorporated in the new formative policies of some countries. Lam, Cheng, and Choy [34] highlight it as a key and innovative element in education. It is based on the intention of engaging the students actively in scenarios similar to the ones they have to confront in the real world, in which they must use their various competences for the planning, management, tracking and evaluation of their job. The students apply the concepts in different stages of the Project according to their needs. This is far from traditional teaching methods where the concepts are accumulated sometimes, but their application in a context is not evident. The role of the student becomes receptive and passive. As Chinnoswsky et al. States [35], the scientific foundation of the project based learning models is to generate learning processes where students are not passive receptors of knowledge.

Blumenfeld et al. [36], proposes that the PBL promotes the bounds between diverse disciplines or topics in a subject, and it adapts to different types of students and learning situations. The PBL definition is found in several publications, [37] and [38], in which common characteristics are identified:

It allows the development of diverse types of competences.

The learning environments are contextualized. They consider restrictions and variables of a real environment.

The learning process revolves around the student where the activities of co-operation and collaboration with peers are encouraged.

The student builds and regulates the development of the solutions himself through research questions and problem formulation.

The teacher role is of a mediator and facilitator during the various stages of the project development.

The products and outcomes can be socialized with different social and cultural actors.

There are several proposals for the execution of a project in the context of formation, [33] and [39]. There are highlighted aspects in them such as: fields of application, project duration, number of team members, as well as the way how the students collaborate and co-operate. In [38] and [40], the various types of projects that can be implemented in the formation are recognized, which are classified according to aspects such as the project duration time, the formation level of people that will take place, and the dimension of the project. Köse [41] recognizes the benefits and difficulties in project based learning.

Van den Bergh et al. [22] highlights two main disadvantages of the PBL: the workload and the differences between various projects, particularly concerning to the organization and assessment. In the same way, the motivational elements in students, the cognitive overload of the project, and the traditional teaching practices deeply rooted in teachers which have a direct impact in the realization of a project are identified. 


\section{Related Works}

Currently, there are different tools, methodologies, and models for assessment supported by technology that allows making valuations within the students' formative processes. Table 3 shows a description based on [7].

Table 3: Assessment Model

\begin{tabular}{ll}
\hline \multicolumn{1}{c}{ Model } & \multicolumn{1}{c}{ Description } \\
\hline $\begin{array}{l}\text { Evidence-Centered } \\
\text { Assessment Design [42] }\end{array}$ & $\begin{array}{l}\text { Evidence-based approach that allows the design from a set of rules defined in a } \\
\text { user model }\end{array}$ \\
$\begin{array}{l}\text { Modeling assessment for } \\
\text { re-use of assessment [21] }\end{array}$ & $\begin{array}{l}\text { of all the phases of the assessment process; it is a model that supports various } \\
\text { types of assessment. } \\
\text { A formative evaluation model within a competency-based approach, which } \\
\text { considers individual paths for the formation and assessment of students' } \\
\text { Model [43] }\end{array}$ \\
\hline
\end{tabular}

A search and analysis of related works done that apply pedagogical strategies for the formation using the PBL method are presented in Table 4.

Table 4: Academic projects with PBL

\begin{tabular}{|c|c|}
\hline Project & Description \\
\hline $\begin{array}{l}\text { Student teams in } \\
\text { computer science [39] }\end{array}$ & $\begin{array}{l}\text { Students develop a software project, and teamwork is encouraged by doing } \\
\text { implementation and testing activities. }\end{array}$ \\
\hline Database design [44] & $\begin{array}{l}\text { Students in work teams must make the implementation of a database } \\
\text { considering the requirements of a real project. }\end{array}$ \\
\hline $\begin{array}{ll}\text { Educational } & \text { Software } \\
\text { Course }[45] & \end{array}$ & $\begin{array}{l}\text { A course of educational software was implemented, where students will } \\
\text { develop software with quality criteria. The portfolio assessment method was } \\
\text { used. }\end{array}$ \\
\hline Physics lessons [37] & $\begin{array}{l}\text { A proposal to implement a learning strategy for the development of } \\
\text { communication skills in a physics course. }\end{array}$ \\
\hline $\begin{array}{l}\text { Linear control systems } \\
\text { [46] }\end{array}$ & $\begin{array}{l}\text { It presents a pedagogical strategy per projects in a linear control systems } \\
\text { course for the development of professional skills. }\end{array}$ \\
\hline
\end{tabular}

The works presented are mostly applied in the engineering area and resulted in positive experiences during the learning process of students. Also, there are research reports that were based on PBL with technological support in the process of formation students. Table 5 shows some of them.

Table 5: Academic projects with E-learning support

\begin{tabular}{ll}
\hline \multicolumn{1}{c}{ Project } & \multicolumn{1}{c}{ Description } \\
\hline Hydro-LCMS & Learning Content Management System for hydrologic engineering courses. \\
environment [47] & It was created to support project-learning services for students and teachers. \\
Programming course & A system to support learning activities based on projects in a design and web \\
[41] & programming course. \\
Project management e- & $\begin{array}{l}\text { Design of an online course for the formation in project management taking } \\
\text { course [48] }\end{array}$ \\
\hline
\end{tabular}

There are models to manage the activities of PBL, Milentijevic, Ciric and Vojinovic, [49] propose a model that supports different PBL approaches; and using a version control, it allows both teachers and students to monitor the different stages of a project.

\section{Formative Projects}

The conceptions of Kilpatrick [29] were subsequently taken up by educators. These have been expanded, restated, and articulated to different pedagogical models and teaching strategies. One of these proposals is the socioformative approach, which is a framework for educational reflection and action that aims to create the essential pedagogical conditions to facilitate the integral development of people. Besides, it seeks to train people with a strong ethical life plan, entrepreneurship, collaborative work, and the necessary skills to meet challenges of the context [3] and [50]. 
The methodology of competence evaluation and formation of this approach is essentially through formation projects. A formation project is a coordinated set of activities that are deployed in time to solve a problem situation and contribute to form one or more competences based on criteria and evidence [3] and [50]. The formation projects have three main purposes [18]:

To conduct a systematic formation of competences by integrating the how-to do with the how-to know and how-to be.

To know, understand, and solve reality problems according to the interests of students.

To learn to understand and build a reality as a controversial topic with strategic recognition and confrontation of uncertainty.

A formation project can be structured through a Formative Route (FR), which is an instrument that the whole methodological process for the development and evaluation of student competencies is oriented. The formative route is the organizational element that directs the formative project through phases and the implementation of activities where students can achieve higher levels of performance. The description of the phases in a formation project is shown in Table 6.

Table 6: Formative Project Activities

\begin{tabular}{ll}
\hline \multicolumn{1}{c}{ Phase } & \multicolumn{1}{c}{ Description } \\
\hline Addressing the project & $\begin{array}{l}\text { The formation route is agreed, and the criteria necessary to be considered are } \\
\text { established. } \\
\text { The students plan along with the teacher a project in concordance with the } \\
\text { general course project. }\end{array}$ \\
Executing the project & $\begin{array}{l}\text { The students execute the Project with the mediation of the teacher. } \\
\text { The students, with the mediation of the teacher, present the general report of } \\
\text { the project. }\end{array}$ \\
\hline
\end{tabular}

In these phases, students and teachers participate. Its fundamental purpose is to articulate the whole learning process and the assessment of competences. In Fig 1, a sequence diagram with the teacher and student interactions in a Formative Project (FP) is shown.

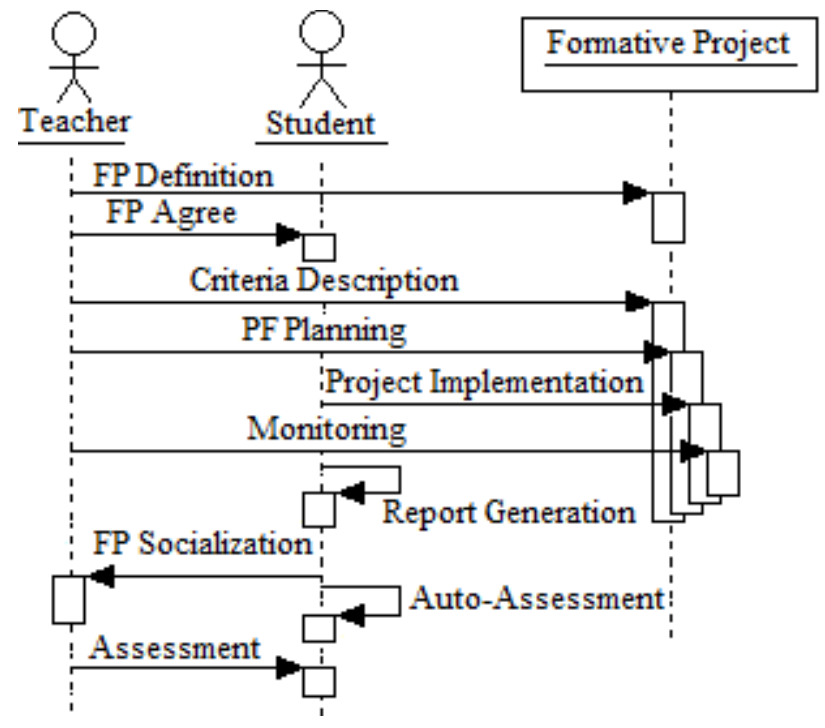

Figure 1: Interactions in a Formative Project

In each phase, the activities in which there is direct interaction with the teacher, as well as those that include independent and autonomous work from the student are programmed. For each of the phases, the aspects of assessment, which are detailed in the next section, are considered.

\subsection{Assessment Competences}

The assessment of competences is conducted essentially looking for students to solve context problems and submit one or several evidences for which exist as reference some key criteria [7]. Based on these elements, the level of 
student performance, achievements and concrete actions to improve are determined. During the process, students must submit evidence generated in the implementation of the project, which are evaluated according to domain levels. The assessment is based on proficiency levels: pre-formal, receptive, basic, autonomous y strategic. These criteria can be applied to a criterion or a competency. These proficiency levels are shown in Fig 2.

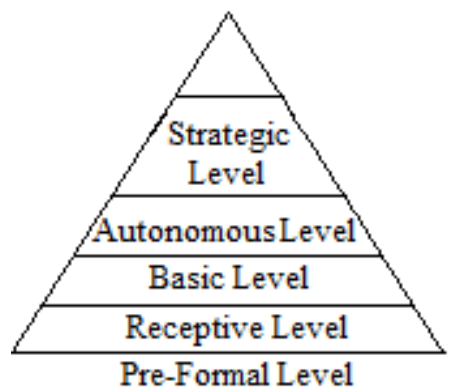

Figure 2: Proficiency Levels

Table 7 describes the main characteristics of the proficiency levels [3].

Table 7: Proficiency Levels

\begin{tabular}{ll}
\hline \multicolumn{1}{c}{ Level } & \multicolumn{1}{c}{ Description } \\
\hline Pre-formal & The person acts before the problems without clarity of guidance. \\
Receptive & $\begin{array}{l}\text { The person acts before the problems with some notions. Performance is very } \\
\text { operational and mechanical. }\end{array}$ \\
Basic & $\begin{array}{l}\text { The person acts before the problems understanding basic procedures. } \\
\text { Autonomous }\end{array}$ \\
The person acts autonomously before the problems. \\
Strategic & $\begin{array}{l}\text { The person acts before the problems achieving impact. The consequences of } \\
\text { different options of problem solving in context are considered. }\end{array}$ \\
\hline
\end{tabular}

The assessment process requires a sequence of activities where the definition of competences, criteria, and its related evidence, makes possible to define a learning map (rubrics by competences) that considers different types of assessment and its corresponding feedback [7]. Likewise, this process should be supported by different instruments to ensure the monitoring and obtaining of the student formative purposes. For Tobón [3], a matrix configured by proficiency levels is by itself a learning map. The learning maps are tables of double input in which the criteria of the competences along with the proficiency levels are related, and the students' evidences are integrated [3].

This instrument requires validation between teachers and students in order to make adjustments that ensure the competence assessment process. The generic structure of a learning map is presented in Table 8:

Table 8: Learning Map

\begin{tabular}{|l|l|l|l|}
\hline \multicolumn{4}{|l|}{ Description of the competency to be evaluated } \\
\hline Assessment process & Assessment moments & Assessment \\
\hline Criteria & Evidence & Proficiency level & Assessment to be made \\
\hline $\begin{array}{l}\text { Criterion } \\
\text { description }\end{array}$ & Evidence description & Proficiency description and Assention \\
\hline
\end{tabular}

Based on the elements described, the model presented in the next section is proposed.

\section{Proposed Model}

The information model is based on the socioformative approach, and it constitutes a base element for the construction of adaptive virtual scenarios that allow the formation and assessment of competences through formation projects. The technological platform will be a Learning Management System (LMS), which will integrate an adaptive system that allows the personalization of virtual courses. 
The adaptive systems automatically adapt to the users based on assumptions of the system about their needs [51]. Its main objective is to improve the relationship with the user (presentation of content, navigation interfaces) according to a student model that considers his goals, preferences, knowledge and/or interactions, among others [16].

The most commonly used LMS environments in e-learning processes in educational institutions allow the management of learning content. They have mechanisms of communication between the teacher and the student, and they give support to the assessment of students. Moreover, the LMS usually do not take into account individual differences of students, their learning needs and characteristics [52]. Several investigations report problems with the relation of the customization in the LMS [53], and [52], where it generally stands out that no customization services are offered, and students are given access to the same set of educational resources, ignoring individual differences of the students such as: level of competences, interests, necessities, characteristics and motivations. Although, there has been efforts to customize LMS, works like [2] and [54], have been of research nature, and the social and productive appropriation of this knowledge has been limited. In addition to not providing an adequate level of adaptability of content and services, LMS adaptation requires the development of new software modules, which may become obsolete and incompatible with new versions of LMS [53].

The architecture includes three components: the supporting tools, the LMS, and the adaptive system, which are shown in Fig 3. The learning resources, the courses, and the information of users enrolled in the LMS are managed through the LMS.

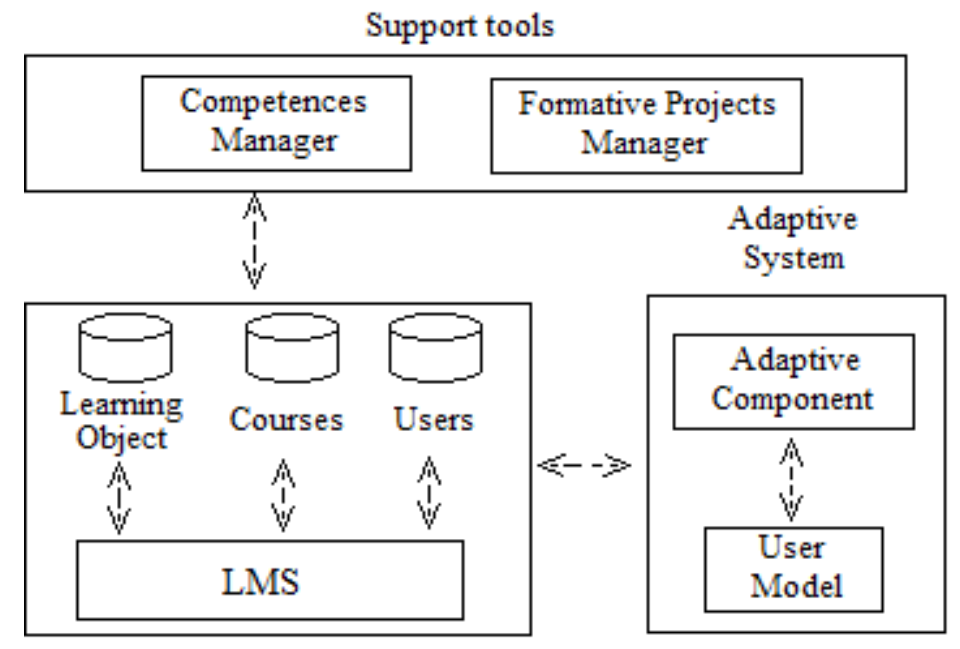

Figure 3. LMS Extension Architecture

The support tools are software applications that allow the management of competences and formative projects. The formative project administrator is the application that supports the design of the projects by teachers. The formative project, competences, activities, and elements for evaluation are defined there.

In the adaptive system, the adaptive component is responsible for carrying out the task of customizing learning objects. The student model is a source of knowledge that contains user aspects that may be relevant to the behavior of the system [2]. This model is responsible for storing all the information about the user. [2] highlights some of them:

$\therefore \quad$ User Dimension characteristic: the variables associated with the student are included: competence level, learning objectives, prior knowledge, and learning styles.

$\therefore$ Context Dimension: those variables describing the environment or circumstances of a student when following a course/learning unit are included. Some of the variables considered in this dimension are: access device type, bandwidth, operating system, user software, and text size.

$\therefore \quad$ Interaction Dimension: all the aspects that can be inferred from the use of the platform by the student are included. Some variables that may be included are: number of sessions, duration per session, contributions made in forums.

\subsection{Formative Model Project}

The formative project must be designed in phases and activities. Likewise, the formative project consists of one or more competences which are associated with criteria and evidence. In Fig 4, a UML diagram that represents the model that has been validated in [7] is shown. 


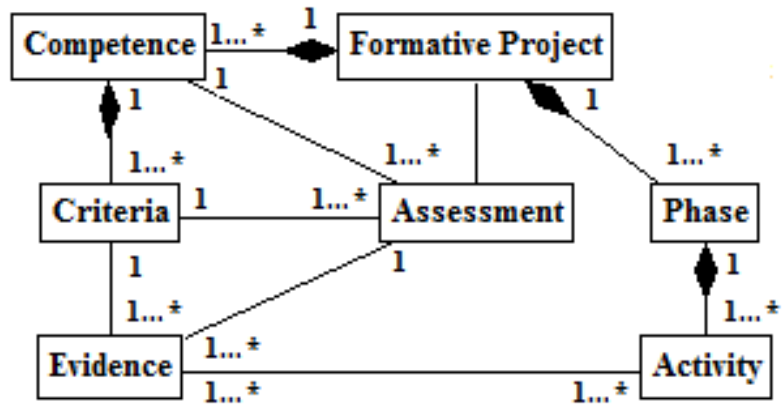

Figure 4: Formative project components

The elements of a formative project are described in Table 9.

Table 9: Description of activities of a Formative Project.

\begin{tabular}{|c|c|}
\hline Level & Description \\
\hline $\begin{array}{l}\text { Formative } \\
\text { Project }\end{array}$ & $\begin{array}{l}\text { It is a set of activities that are planned, executed, and socialized to solve a context } \\
\text { problem, and to ensure the formation of competences [3]. }\end{array}$ \\
\hline Competences & $\begin{array}{l}\text { They are integral actions to solve context problems with suitability, ethics, and meta- } \\
\text { cognition. }\end{array}$ \\
\hline Criteria & $\begin{array}{l}\text { They are specific guidelines to orient the learning and evaluation of competences. } \\
\text { They establish the essential goals to be considered in a grade or academic period [3]. }\end{array}$ \\
\hline Evidences & $\begin{array}{l}\text { They are the products necessary to evaluate the learning outcomes established as } \\
\text { criteria. }\end{array}$ \\
\hline Assesment & $\begin{array}{l}\text { Set of activities that allow the assessment of competences in accordance with defined } \\
\text { criteria. }\end{array}$ \\
\hline Phase & $\begin{array}{l}\text { Scenario where the learning activities necessary for students to achieve the defined } \\
\text { criteria are established. }\end{array}$ \\
\hline Activity & Specific action to be performed within the formative process. \\
\hline
\end{tabular}

As a key element, the assessment of competences, which is explained below, stands out.

\subsection{Assessment Model}

For the assessment of competences, it is necessary that teachers and students can verify and validate their activities within the formative process. The assessment of competences is based on criteria supported by evidence. The structural elements of the assessment under the socioformative approach are shown in the UML diagram in Fig 5, which has been validated in [7].

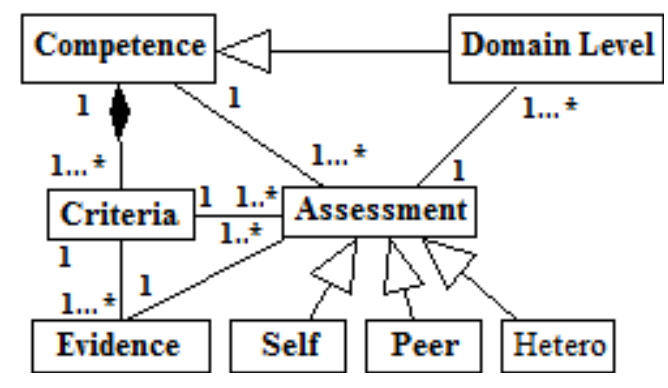

Figure 5: Assessment Model

Interdependent processes of assessment that are considered within a formative project are: self-assessment, peer assessment and hetero assessment. They are defined in table 2.

\subsection{Model Validation}


The validation of the model allows determining if the design meets the abstraction of the domain under study. In this context, two models (formative and assessment projects) that describe the elements for the formation and evaluation of competences were designed. A UML diagram with its classes of implementation is presented in Fig 6.

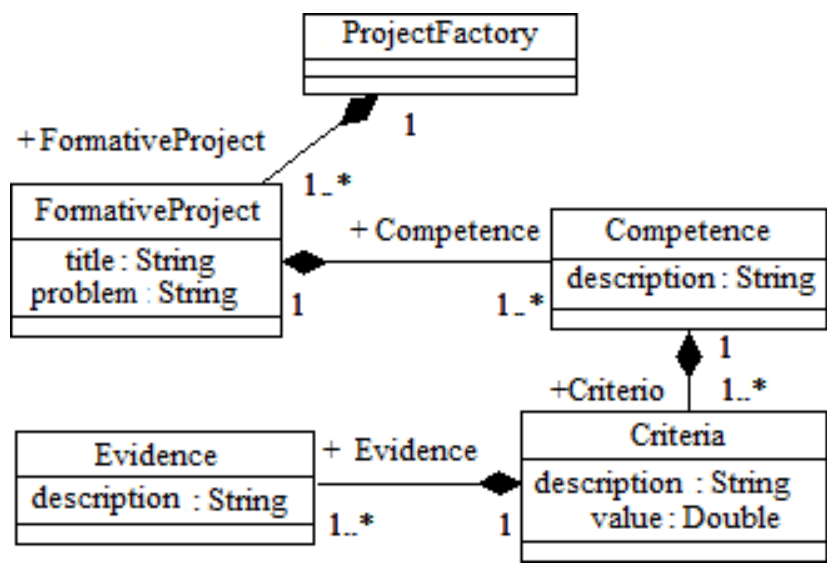

Figure 6: Implementation Classes

To validate the model, it is considered a subset of elements from Figure 4, because the main aspects of the formative projects are based in them.

There are frameworks that support the modeling activities with various technologies. Within this are: the Eclipse Modeling Framework (EMF) and the Graphical Modeling Framework (GMF). They are modeling and code generation frameworks for application construction based on a structured data model [55]. These tools ensure interoperability between different classes of technology platforms. Through the creation of an EMF project, all the model properties from Figure 6 are imported, and they are converted to a model definition language called Ecore that validates its semantic structure. In the model, a class called project factory, which allows the creation of different formation projects, is included.

The eclipse environment displays the ecore model shown in Fig 7 by a hierarchical structure with the classes, attributes, and relationships. For example for the competence design class, an attribute of the string type and their relationships with the competence and formative project class is shown.

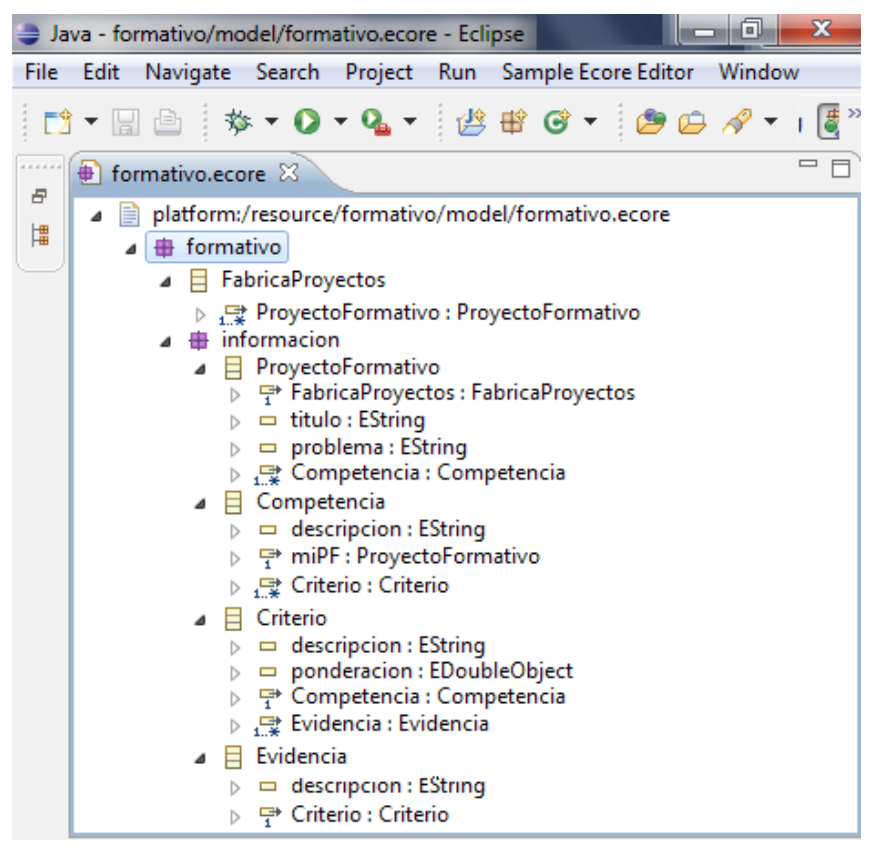

Figure 7: Ecore Model

Starting from the ecore model and using the GMF editor, it is possible to generate various productions or model checking. The name of the formative project was called pedagogical practices. This formative project in turn has two competences defined: teamwork and competence assessment. The teamwork competence has in turn the criterion: I 
participate in team activities. Two evidences are also defined: a mental map and a document. A concrete production of the model can be seen in Fig 8.

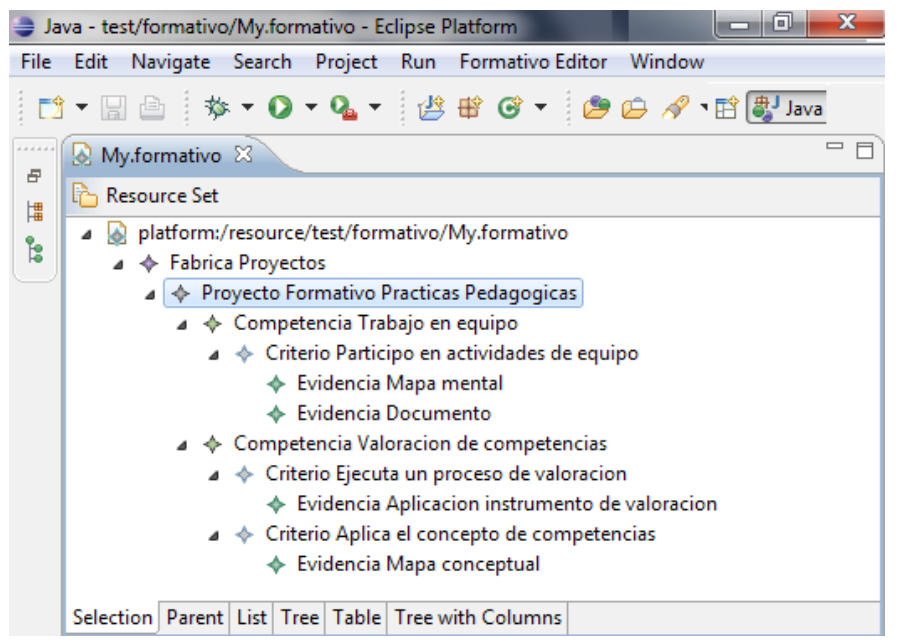

Figure 8: Ecore Model Production

Through an implicit EMF editor, it is possible to generate the eXtensible Markup Language (XML) of the ecore model. In Table 10, an XML document, which is a representation of the ecore production from Figure 8, is shown.

Table 10: Formative Project XML Document

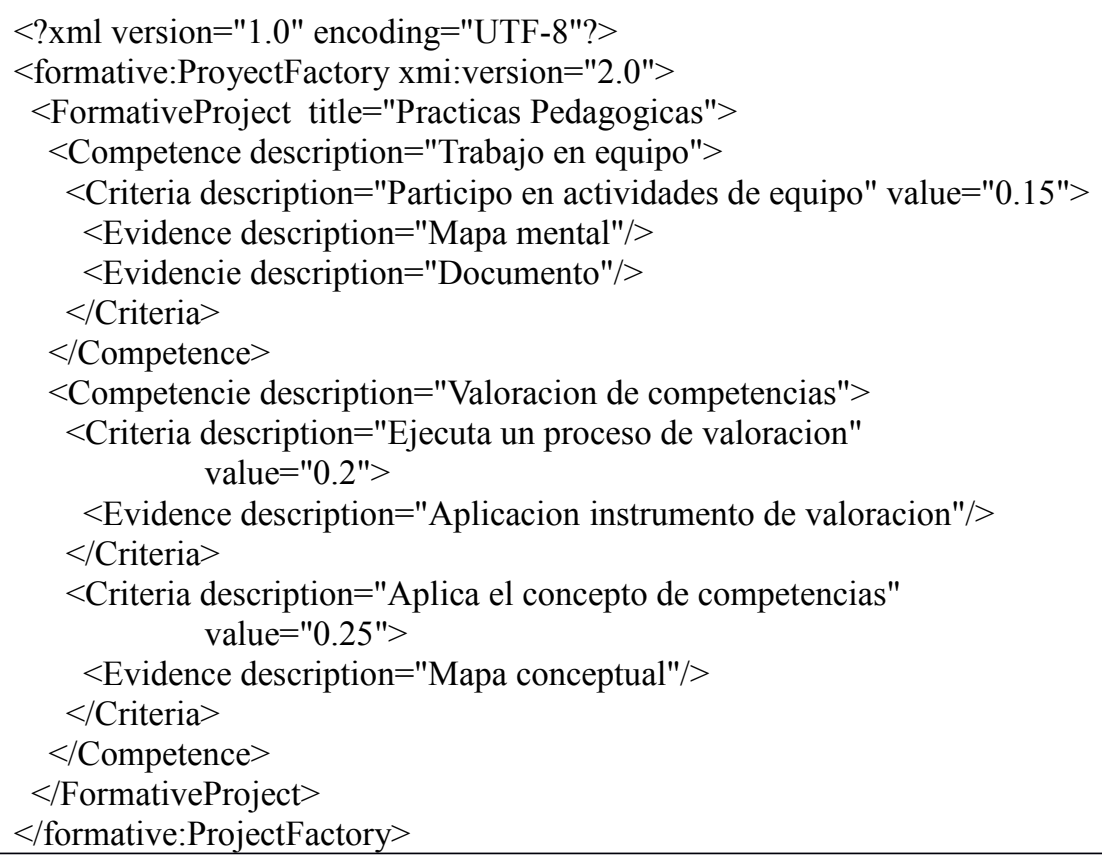

An application case is presented in a virtual course in the next section, and this intends to show the correspondence with the model.

\section{Application Case}

As an application case, an example of a competence evaluation in the Diplomat of Didactic Strategies and Evaluation, which is offered through the virtual mode in the CIFE University Corporation of Mexico, is presented. Table 11 shows a matrix (rubrics) that relates the criteria with the evidence, and the proficiency expected.

Table 11: Learning Map 
Description of the competition to be evaluated:

It mediates the formative, learning and assessment processes, so students develop the competences of the graduate profile consistent with the core curriculum.

Context problem:

Implementing competences with a group of people integrating teaching strategies and assessment tools from the socioformation. The people can be students or members of an organization.

Evaluation Process:

In each phase, evidence that the project is a product made in the diplomat must be presented.

Times of assessment:

It will take place at the beginning of the program (self-assessment), during the formative process, and at the end of each phase of the diplomat.

\begin{tabular}{|l|l|l|}
\hline \multicolumn{1}{|c|}{ Criterion } & \multicolumn{1}{|c|}{ Evidence } & \multicolumn{1}{c|}{ Domain level } \\
\hline $\begin{array}{l}\text { It applies the concept of competence in } \\
\text { the teaching practice based on the } \\
\text { conceptual cartography. }\end{array}$ & $\begin{array}{l}\text { Conceptual cartography report of } \\
\text { the competences approach and } \\
\text { its application in practice. }\end{array}$ & $\begin{array}{l}\text { Resolutive: performance with } \\
\text { concepts and tool reproduction } \\
\text { without understanding. }\end{array}$ \\
\hline
\end{tabular}

In the rubrics, the description of the five proficiency levels associated with a criterion always appears. The virtual environment of the diplomat course is designed by phases, which always retains the same structure of activities to be performed by students. In Fig 9, the basic design of a virtual diplomat course is shown.

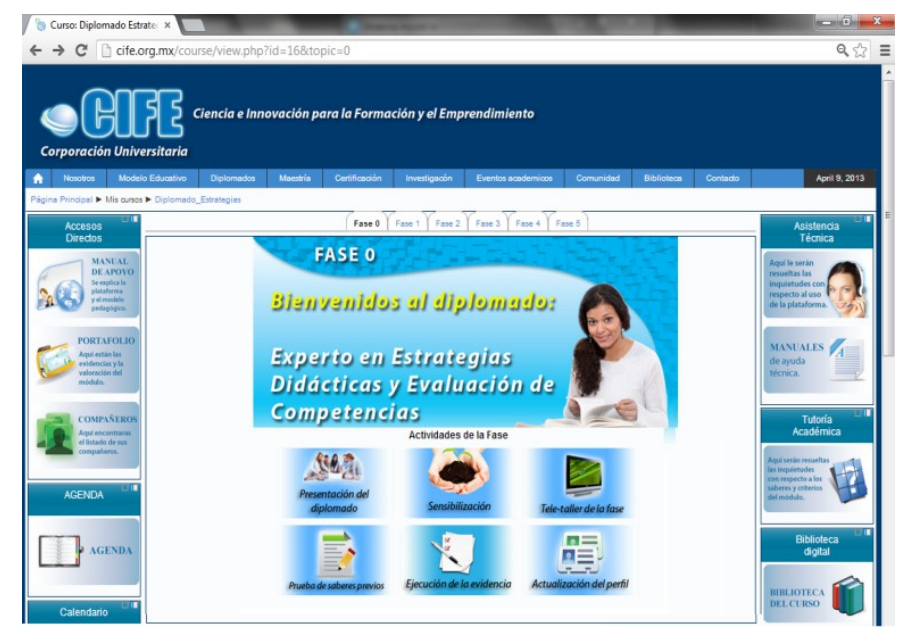

Figure 9: Design of a Virtual Diplomat

The instructional design of the graduate shows the activities to be performed. For example, for Phase 1 the sensitization, self-evaluation, socialization of evidence, among others is defined. Each one of these activities has different learning objects that support formation. In Fig 10, the structure of phase 1 is shown in greater detail. 


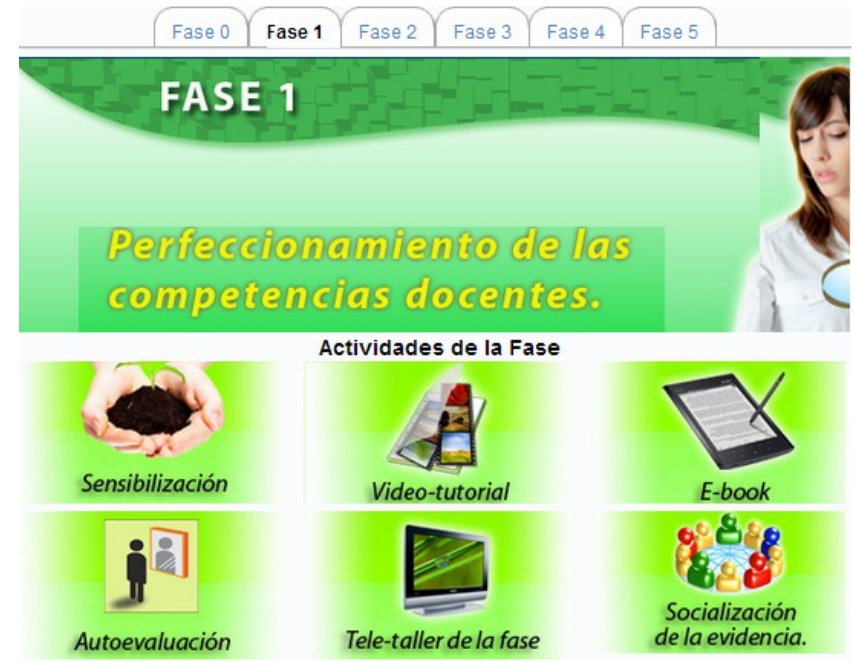

Figure 10: Phase Activities

In each phase, the criteria, the evidence, the weight of the evidence, the description of the activities to be done, and the time for their implementation are defined. These aspects are defined in the virtual course as shown in Fig 11.

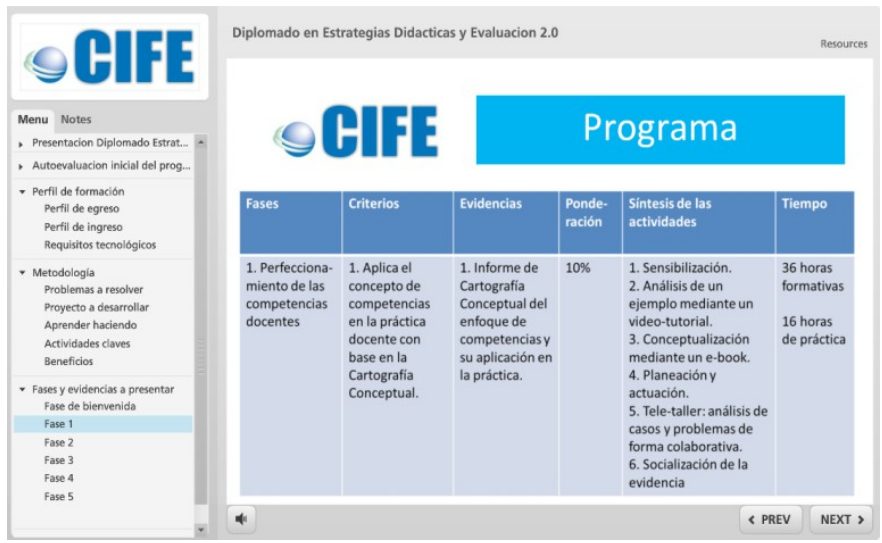

Figure 11: Competence Assessment Sequence

The learning process of the student revolves around a formative project that provides progressively the activities that must be performed for the competence goal. This case study covers only the aspects taken in the model, i.e., the part of the project creation and the definition of competences, criteria and evidence for it. The description of the formative project to be done within the diplomat is shown in Fig 12.

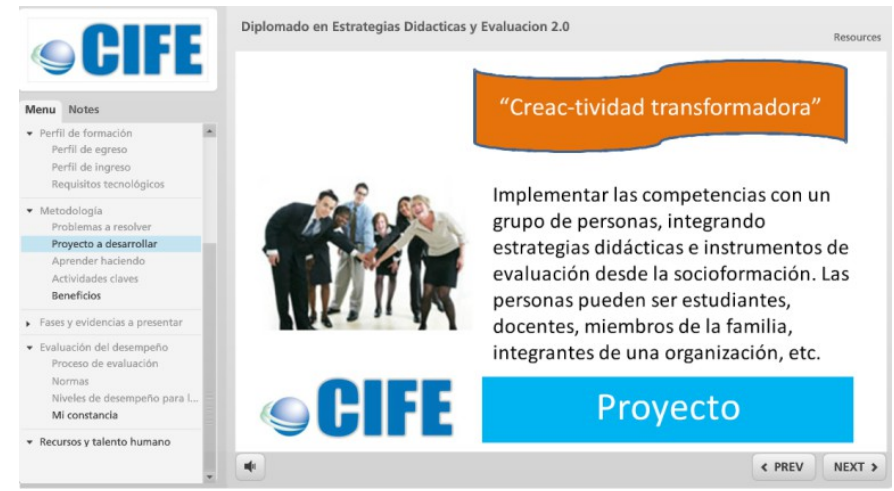

Figure 12: Formative Project Definition

In the CIFE virtual formation, 23 virtual Diplomats were given in Latin America in countries such as Chile, Colombia, Venezuela, Ecuador, Mexico and Bolivia. 


\section{Conclusions}

In a process of competence formation, different types of knowledge of the human performance are considered. They relate ethical issues and emphasize attitudes, skills and knowledge, which are necessary to address and resolve context problems. The integration of these aspects has transformed the assessment in education where it is emphasized on formative assessment oriented towards the diagnosis and valuation of integrated actions before environment problems. The socioformative approach highlights the recognition and appreciative nature of the evaluation during the different stages of the formative process, in which the diagnostic evaluation is contemplated, continuous, for the accreditation and socio-evaluation where it is required the definition and planning of monitoring and feedback.

Project-based learning places the student as the core of the formative process where he must display his skills in scenarios very similar to the real world, which he should display his various competences for planning, management, monitoring and evaluation of his work. Based on its main concepts, there is a methodology of the formative projects which are aimed at the formation and assessment of competences through an articulated set of actions of planning, acting, and communication.

With the review of the related work, it is identified that there are different types of pedagogical strategies and technological tools that support the development of competences in students today. In all such cases, the method of learning through projects where it is clear the use of various formative methodologies; teamwork, the assignment of roles, and collaborative work stands out. Regarding the assessment form it was identified that in many cases the course assessment is summative, and focused on cognitive aspects and disciplinary content, without being explicit the student feedback in the learning process. It was identified only in a couple of jobs that the portfolio method was used for evaluating students.

In this context from the socioformative approach, a model based in the methodology of the formative projects was designed, in which the definition of competencies, the assessment criteria and the delivery of evidence is possible. The assessment model includes the proficiency levels of competence and the types of assessment applicable during the formative process of students.

The proposed model meets the characteristics of development and assessment of competences of the socioformative approach. The model validation was performed using the EMF and GMF frameworks, which are supported by code generating technological tools that guarantee the semantic and syntactic correctness. Likewise, this validation allows to state that the model meets the abstraction of the domain, and this is reflected in the virtual formative courses of the CIFE University Corporation where the phases, activities, formative projects, and competence assessment are defined.

As a future work, it should be designed a multidimensional model of a student that considers the individual differences of students based on proficiency levels. Additionally, it must be implemented an architecture to personalize the educational experience of students through a virtual learning environment.

\section{Acknowledgements}

The members of this paper thank the Administrative Department of Science, Technology and Innovation Colciencias, convening 569 of 2012, for the financial support of the research project: Adaptive Learning Environment Based on a Multidimensional Student Model, code 142556935016.

\section{References}

[1] J. Kim, "Education reform policies and classroom teaching in South Korea," Int. Stud. Sociol. Educ., vol. 14, pp. 125-145, 2004.

[2] J. Velez, "Entorno de aprendizaje virtual adaptativo soportado por un modelo de usuario integral," Universitad de Girona, 2009.

[3] S. Tobón, Formación integral y competencias, Tercera Ed. Bogotá: ECOE Ediciones, 2010, p. 328.

[4] Á. Díaz-barriga, "El enfoque de competencias en la educación. ¿Una alternativa o un disfraz de cambio?," Perfiles Educ., vol. XXVIII, no. 111, pp. 7-36, 2006.

[5] A. Gonczi and J. Athanasou, Instrumentación de la educación basada en competencias. Perspectiva de la teoría y la práctica en Australia, Limusa. Mexico, 1996, pp. 274-275.

[6] H. Biemans, L. Nieuwenhuis, R. Poell, M. Mulder, and R. Wesselink, "Competence-based VET in the Netherlands : background and pitfalls," Vocat. Educ. Train., vol. 56, no. 4, pp. 523-538, 2005.

[7] S. Cardona, J. Velez, and S. Tobón, "Towards a model for assessing competencies," in Computing Colombian Conference (8CCC), 2013, pp. 109-114.

[8] S. Cardona, J. Velez, and S. Tobón, "Towards an adaptive system based on competences," in 6th COLCOM - IEEE Colombian Conference on Communications and Computer, 2013, pp. 1-6.

[9] A. Ouellet, "La evaluación informativa al servicio de las competencias," Rev. Esc. Adm. negocios, vol. 41, pp. $30-42,2000$. 
[10] P. Perrenoud, Diez nuevas competencias para enseñar, GRAO. Barcelona, 2004, p. 168.

[11] DeSeCo, "The definition and selection of key competencies," 2005.

[12] E. Tuning, "Tuning educational structures in Europe," Bilbao, 2006.

[13] Á. Díaz-barriga, "Competencias en educación . Corrientes de pensamiento e implicaciones para el currículo y el trabajo en el aula," Rev. Iberoam. Educ. Super., vol. 2, no. 5, pp. 3-24, 2011.

[14] I. Gómez, "Competencias profesionales: una propuesta de evaluación para Las facultades de ciencias administrativas," Educ. y Educ., vol. 8, pp. 45-66, 2005.

[15] G. Bunk, "La transmisión de las competencias en la for mación y perfeccio namiento profesionales de la RFA,” Rev. Eur., vol. 1, pp. 8-14, 1994.

[16] M. Mulder, T. Weigel, and K. Collins, "The concept of competence in the development of vocational education and training in selected EU member states - a critical analysis," J. Vocat. Educ. Train., vol. 59, no. 1 , pp. $65-85,2006$.

[17] J. Tardif, "Desarrollo de un programa por competencias: De la intención a su implementación," Rev. Curric. y Form. del Profr., vol. 16, no. 3, pp. 36-45, 2008.

[18] S. Tobón, Formación basada en competencias, ECOE. Bogotá, 2005, pp. 1-286.

[19] E. Quellmalz and J. Pellegrino, “Technology and testing,” Science (80-. )., vol. 323, pp. 75-79, Jan. 2009.

[20] M. Zabalza, Competencias docentes del profesorado universitario, Narcea. Madrid, 2007, p. 256.

[21] D. Joosten-ten Brinke, J. van Bruggen, H. Hermans, J. Burgers, B. Giesbers, R. Koper, and I. Latour, "Modeling assessment for re-use of traditional and new types of assessment," Comput. Human Behav., vol. 23, no. 6, pp. 2721-2741, Nov. 2007.

[22] V. Van den Bergh, D. Mortelmans, P. Spooren, P. Van Petegem, D. Gijbels, and G. Vanthournout, "New assessment modes within project-based education - the stakeholders," Stud. Educ. Eval., vol. 32, no. 4, pp. 345-368, Jan. 2006.

[23] N. El Faddouli, B. El Falaki, M. K. Idrissi, and S. Bennani, "Towards an adaptive competency-based learning system using assessment," Int. J. Comput. Sci., vol. 8, no. 1, pp. 265-274, 2011.

[24] E. Essa, A. Dittrich, S. Dascalu, and F. C. H. Jr., "ACAT: A web-based software tool to facilitate course assessment for ABET accreditation," in 2010 Seventh international conference on Information technology, 2010, pp. 88-93.

[25] J. G. Moura, L. O. Brandão, and A. A. F. Brandão, “A web-based learning management system with automatic assessment resources," in Frontiers in education conference - Global engineering, 2007, pp. 1-6.

[26] C. C. Marinagi, V. G. Kaburlasos, and V. T. Tsoukalas, "An architecture for an adaptive assessment tool," in 37 Th annual frontiers in education conference, 2007, pp. 11-16.

[27] C. Smaill, "The Implementation and Evaluation of OASIS, a Web-Based Learning and Assessment Tool," in Proceedings. Frontiers in education. 36th Annual Conference, 2006, pp. 1-6.

[28] J. Minstrell and P. Kraus, "Guided inquiry in the science classroom," in in How students learn: history, mathematics, and science in the classroom, S. Donovan and J. Bransford, Eds. Washington, 2005, pp. 475513.

[29] W. H. Kilpatrick, "The Project Method,” Teach. Coll., vol. 19, pp. 319-335, 1918.

[30] K. Adderley, C. Ashwin, P. Bradbury, J. Freeman, S. Goodlad, J. Greene, D. Jenkins, J. Rae, and O. Uren, "Project methods in higher education, SRHE working party on teaching methods: techniques group.," Guildford, 1975.

[31] N. Osada and N. Miyake, "From CSCL classroom to real-world settings through project-based learning," in Proceedings of the conference on Computer support for collaborative learning, 2005, pp. 479-483.

[32] R. Pucher and M. Lehner, "Project Based Learning in Computer Science - A Review of More than 500 Projects," Procedia - Soc. Behav. Sci., vol. 29, no. 2010, pp. 1561-1566, Jan. 2011.

[33] L. Arpin and L. Capra, L'apprentissage par projets. Montreal: Chenelière/McGraw-Hill, 2001.

[34] S. Lam, R. W. Cheng, and H. C. Choy, "School support and teacher motivation to implement project-based learning," Learn. Instr., vol. 20, no. 6, pp. 487-497, Dec. 2010.

[35] P. S. Chinowsky, H. Brown, A. Szajnman, and A. Realph, "Developing Knowledge Landscapes through Project-Based Learning,” J. Prof. issues Eng. Educ. Pract., vol. 132, no. 2, pp. 118-124, 2006.

[36] P. Blumenfeld, E. Soloway, R. Marx, J. Krajcik, M. Guzdial, and A. Palincsar, "Motivating project-based learning: Sustaining the doing, supporting the learning," Educ. Psychol., vol. 26, no. 3, pp. 369-398, 1991.

[37] M. Garabet and C. Miron, "The development of the oral communicative ability at pupils during the physics lessons through the project method," Procedia - Soc. Behav. Sci., vol. 2, no. 2, pp. 5130-5138, Jan. 2010.

[38] J. Proulx, Apprentissage par projet. Quebec: Presses de l'Université du Québec, 2004.

[39] A. Breiter, G. Fey, and R. Drechsler, "Project-based learning in student teams in computer science education," Electron. Energ. Spec. issue Comput. Sci. Educ., vol. 18, no. 2, pp. 165-180, 2005. 
[40] A. Morgan, "Theoretical aspects of project-based learning in higher education,” Br. J. Educ. Technol., vol. 1, pp. 66-78, 1983.

[41] U. Köse, "A web based system for project-based learning activities in 'web design and programming' course,” Procedia - Soc. Behav. Sci., vol. 2, no. 2, pp. 1174-1184, Jan. 2010.

[42] R. J. Mislevy, L. S. Steinberg, F. J. Breyer, R. G. Almond, and L. Johnson, "Making sense of data from complex assessments." Princeton, p. 40, 1999.

[43] E. F. Brahim, K. I. Mohammed, and B. Samir, "A formative assessment model within the competencybased-approach for an individualized e-learning path,” World Acad. Sci. Eng. Technol., vol. 40, pp. 208-212, 2010.

[44] C. Domínguez and A. Jaime, "Database design learning: A project-based approach organized through a course management system," Comput. Educ., vol. 55, no. 3, pp. 1312-1320, Nov. 2010.

[45] Y. Gülbahar and H. Tinmaz, "Implementing project-based learning and e-portfolio assessment in an undergraduate course," Int. Soc. Technol. Educ., vol. 5191, pp. 309-327, 2006.

[46] E. Núñez, L. Fernández, and J. Ramírez, “Aproximación al aprendizaje por proyectos en sistemas lineales de control," Rev. Energíay Comput., vol. 16, no. 2, pp. 1-9, 2008.

[47] O. Jian, D. Yi-ning, and Y. Jin-sheng, "Design and Application of a Project-Based Teaching Environment," in International Conference on Computer Technology and Development, 2009, pp. 125-129.

[48] H. Keser and D. Karahoca, "Designing a project management e-course by using project based learning," Procedia - Soc. Behav. Sci., vol. 2, no. 2, pp. 5744-5754, Jan. 2010.

[49] I. Milentijevic, V. Ciric, and O. Vojinovic, "Version control in project-based learning," Comput. Educ., vol. 50, no. 4, pp. 1331-1338, May 2008.

[50] S. Tobón, Metodología de gestión curricular. Una perspectiva socioformativa. México: Trillas, 2013.

[51] R. Oppermann, Adaptive user support, Lawrence E. Hillsdale, New Jersey, 1994, pp. 1-13.

[52] S. Graf and Kinshuk, "Advanced Adaptivity in Learning Management Systems by Considering Learning Styles," 2009 IEEE/WIC/ACM Int. Jt. Conf. web Intell. Intell. agent Technol., pp. 235-238, 2009.

[53] M. Despotović-zrakić, A. Marković, Z. Bogdanović, D. Barać, and J. Ilića, "Providing adaptivity in Moodle LMS courses ddaptive e-learning systems," Educ. Technol. Soc., vol. 15, no. 1, pp. 326-338, 2012.

[54] S. Graf, T.-C. Liu, and Kinshuk, "Analysis of learners' navigational behaviour and their learning styles in an online course," J. Comput. Assist. Learn., vol. 26, no. 2, pp. 116-131, Mar. 2010.

[55] Eclipse, "Eclipse Modeling Framework Project," 2013. [Online]. Available: http://www.eclipse.org/modeling/emf/. [Accessed: 12-Apr-2013]. 